\title{
Islamism in the Post-Arab Spring World
}

Istanbul Think-House (IDE), a self-supported independent research center that promotes the free circulation of ideas, analyzed "Islamism in the Post-Arab Spring World" during its October 24-26, 2014, international conference. Istanbul University's Political Science Faculty Alumni Association and the Association for Human Rights and Solidarity with the Oppressed (MAZLUMDER) hosted the event on their premises.

In his opening remarks on Friday morning, conference co-chair and IDE's general coordinator Halil Ibrahim Yenigun (Istanbul Commerce University) introduced IDE and explained its vision of (1) producing and circulating ideas without depending on big capital and political power centers and (2) concentrating solely on the good of humanity, especially that of the subaltern. IDE is the outgrowth of national conferences on Islamism held during 2012-13, the first event of which had sparked an almost year-long debate in Turkey about the revival of Islamism.

The morning panel, "New Islamisms," dealt with with important theoretical arguments. Gökhan Sümer (University of Essex) began with a central debate on how to reconcile the constitutional system and the Shari'ah by broaching such questions as to whether democratic constitutions ensuring the basic rights and freedoms could have been passed after the Arab Spring and what is Islam's normative status in these new constitutions. He said that such 
issues challenge both citizens and policymakers, for a large constituency clearly wants a Shari'ah-compliant constitution that also respects human rights. Yusuf Ekinci (Y1ldirım Beyazit University) focused on the transformation of Turkish Islamism and new oppositional Islamisms. After analyzing the last decade, he surveyed several Islamist groups during the AKP period and highlighted the fact that their perspectives transcend identity issues and class segregation, in contrast with those held by the earlier Islamic groups. He proposed that although Islamism is somewhat restricted to smaller groups, it may be able to reproduce itself by emphasizing the long-neglected class politics and labor-capital antagonism by reinterpreting its main texts in favor of the poor and the subjugated.

İlknur Karanfil (Boğaziçi University) contributed to Ekinci's argument on the oppositional Islamic groups that criticize what she calls "neo-Islamism" (i.e., free-market Islamism). Ali Kaya (Erciyes University) touched on "The End of Islamism" debate and argued that it has reduced politics to the state level. He proposed that we look at the political subjectivity of Muslims on the global level as being rooted in a theoretical distinction between the political and politics, and contended that only when Islamism is deemed "political" will its output with regard to subjectivities be duly appreciated. In closing, he added that as long as those who believe that Islam is the best way of life maintain this idea, Islamism will never end.

William Quandt (University of Virginia) launched the afternoon panel, "Current Challenges for Islamism Worldwide," by asking: "Does Obama have a strategy for dealing with the Islamic State (IS)?" He analyzed Obama's statements on the absence of such a strategy during the previous month and indicated possible ways of dealing with the Syrian crisis. He worries that the Syrian civil war might last as long as the Lebanese civil war did, unless the countries involved negotiate long-term solutions, including those that give some power to Baath regime, if not to Assad himself.

Ebtisam Hussein (Cairo University) analyzed the positions and strategies sought by Egypt's Muslim Brothers and Salafists, Salafi prudence, and poweroriented political choices. She explained the striking discrepancy between preand post-2011 Islamism in Egypt. In addition to asserting that Salafists were more cautious about adopting strong and conflictual stances, she maintained that they sought positions that reflected the existent/emerging power structure, as compared to the Muslim Brothers, which gives them a better chance of survival. Meysam Badamchi (Istanbul Şehir University) sought to locate Islamism in different articles of Iran's constitution by critiquing it from the viewpoint of John Rawls' idea of political liberalism. He concluded that the 
guaranteed protection of each and every citizen's basic liberties needs to be backed up by a constitutional amendment. Tahir Abbas (Fatih University) described the British Muslim experience and showed how an insignificant but raucous minority is seemingly drawn toward violent extremism, which he calls "Islamic political radicalism." He provided a sociological perspective derived from qualitative, ethnographic, and interview-based research with various actors. He noted that this small segment now numbers over 5 percent of the country's Muslim community.

The following session, "Islamism and Muslimism," was moderated by Yüksel Taşkın (Marmara University). Neslihan Çevik (University of Virginia) contrasted Islamism with the Muslimism that has emerged as a recent sociological phenomenon, one that is neither radical nor liberal but which nevertheless enabled the AKP's rise to power. Muslimism let the new Muslims get in touch with modernity in a "guilt-free" manner. Yenigün pitted Muslimism against Islamism in order to depict the contrast between the quest for power and the quest for justice. Following a synopsis of the AKP's foundational break with Islamism during its emergence, he maintained that the party's current turn toward Islamization policies should not be considered as a new instance of Islamism, but rather as another phenomenon entirely: Muslimism as a solely Muslim power project. In contrast, Islamism should normatively be conceived of as a quest for justice that seeks to speak truth to power and to serve as a witness to justice without seeking power for itself.

The second day's first panel, "Islamism, Power, and Democracy" started out with İsmail Hakkı Akkuş (Istanbul Commerce University) and Mustafa Gedikli's joint presentation on al-Nahda's experience with power in Tunisia. They focused on Rashid Gannushi's leadership as of critical importance and related his political maneuvers to preserve the Jasmine Revolution, which included his party's withdrawal from power. Emrah Kekilli (Istanbul Bilgi University) discussed Libyan Islamism's long-term survival strategies under Muammar al-Qaddafi and underlined how many of the significant political actors who had returned after the revolution were able to mobilize large segments of society. Beytullah Emrah Önce (Free Writers' Union) made some provocative statements, among them "To state that Islamism is dead does not mean Islam is dead." His main critique of Turkish Islamism was that the current power structure's co-optation of Islamist civil society is responsible for its death.

The Saturday afternoon panel featured a roundtable on "Art and Muslim Women in Life" moderated by Feyza Akınerdem (City University London). Cihan Aktaş, a renowned Muslim novelist and architect, discussed the power 
relations between genders and suggested how women can feel at home only if they do not lose touch with their imagination in their work and labor. Another renowned Muslim writer and activist, Yıldız Ramazanoğlu, probed how Muslim women's endeavors in cinema revitalized many underexpressed domains of imagination and how they grappled with portraying the intimate sphere. In addition, she observed how female Muslim directors have chosen the wounds of marriage as the theme of their films. Finally, musician Rümeysa Çamdereli talked about the challenges that she and others have experienced during their engagement with music with reference to Palestinian musician-activist Reem Kelani's experience. She also emphasized that Muslim women's music should not be approached coarsely as harboring some subtle message.

Meanwhile, at the "Islamists in Power" panel, Ibrahim Natil (Coventry and Westminster Universities) asserted that Hamas' ongoing governance crisis will suffer from the setback of the Arab Spring for years to come. Mustafa Oğuzhan Çolak (Istanbul Şehir University) analyzed the AKP's rise to power and subsequent expansion. After presenting the role of the moderate Islamic communities and their own transformation during this process, he concluded that neither Islamist ideology nor neo-liberal policies can solely account for the AKP, which forms its policies in a very pragmatic manner. William Quandt served as the chair and discussant.

In the next session, sole participant Yusuf Enes Sezgin (Istanbul Şehir University) made a case for the "Islamist" anti-apartheid movements. He analyzed the three main Islamist groups that had emerged or became active in South Africa during the 1970s and contributed to the anti-apartheid struggle there during the 1980s, how they designed and initiated their respective policies within a specific context, and how they formed political relationships with other participants in the political struggle.

Muqtedar Khan (University of Delaware) presented the Saturday evening keynote address: "The Future of Islamism and the Demand for the Islamic State after the Arab Spring." After claiming to be "the last Islamist," he said that Islamists have abandoned their aspiration for an Islamic state for political domination. Asking what is Islamic about their envisioned Islamic state, he related this concept's genealogy and compared al-Nahda, the AKP, and other parties with Islamist backgrounds. Remarking that the AKP can only be a model for Tunisia, he observed how "sacred" elections have become in the eyes of these political actors. Thus the issue is not an Islamic state, but "the state of Islam." Moreover, Khan suggested that Islamists view democracy not as desirable because of procedures but because of its normative worth and 
focus on values rather than identity. He added that ideology is supposed to have negative, as opposed to positive, connotations.

Sunday started with a panel on "Democracy and Islamist Moderation" with Muqtedar Khan serving as the chair. Surwandono Wakidi Surjono and Takdir Ali Mukti (University of Muhammadiyah Yogyakarta) illustrated the management pattern of governance led by former rebellion movement activists by comparing MNLF in the Philippines, HAMAS in Palestine, and GAM in Indonesia. Meltem Demircan Özütam (Yeditepe University) assessed the impact of the Arab Spring on Jordan's Islamist movement. She analyzed how and why the country's Muslim Brotherhood replaced its long-held peaceful and reformist strategy with a more rejectionist, confrontational, and at times violent posture that some analysts termed "revolutionary." Özütam also asserted that the Arab Spring would come into play as a profoundly important "contingency" factor with a major triggering impact.

The parallel panel on "Islamism, Locality, and Universality" began with Erdal Kurgan's (Boğaziçi University) examination of the post-1960 Turkish controversies on Islamism as "a non-native" and "non-authentic" discourse based on translations. Abdülkadir Yeler (Marmara University) analyzed the Arab Spring's effect on Turkish Islamism and emphasized that Turkey's policies toward it have affected both its foreign policy and its domestic debates, especially in terms of "the death of Islamism." He discussed what he called the "New Islamism" as having quite distinctive features as regards its discourse, power relations, and views about the West and the Islamic world. İsmail Yurdakök analyzed the tafsïr of Mehmet Vehbi Efendi (1861-1949) in terms of his text on popular sovereignty. He pointed out this religious scholar's strong critique against the Ottoman government for violating the Qur'an's commands. Lütfi Sunar (Istanbul University) served as the chair and discussant.

Merve Kavakçı Islam (Üsküdar University) chaired Sunday afternoon's panel on "Revisiting Islamism, Secularism, and Fanaticism." Ahmad F. Yousif (International Institute of Wasatiyyah, Malaysia) discussed the criteria for establishing whether or not an individual or group is extremist. He stressed that contemporary Muslim scholars frequently find it difficult to define fundamentalism and fanaticism because these concepts did not exist in the early Islamic tradition. Yousif closed by proposing some criteria that could be used to assess a group's fanaticism or fundamentalism. Çevik presented an English-language version of her earlier Turkish presentation on Muslimism.

The final session, "Islamism: An Appraisal and Destination," was a special forum for prominent spokespeople of Turkish Islamism. Alev Erkilet 
(Sakarya University) explored Islamist ideals and their relationship with political power and opined that their desire for power was legitimate; however, how that power would be used must be addressed. By renouncing the phrase "the crisis of Islamism," she stated that Islamism had never died and that at each "end" a group of people will emerge to take on the truth. However, she acknowledged that whenever Islamism encounters a challenge in the social realm, a crisis of legitimacy ensues. Prominent Islamist writer Ali Bulaç's brief narrative of Turkish Islamism argued that just like the first generation Islamists lost their human stock during the Battle of the Dardanelles, the third generation of Turkish Islamists has fallen into a deep sleep.

Academic-activist Cihangir Islam addressed the problem that Muslims aspire to live by their desires but demand that these lifestyles comply with Islam. Theologian Illhami Güler offered his definition of Islamism, in line with that of Bobby Sayyid, as a conception that people use as a reference point to solve their political, economic, and social problems. He underlined the corruption that theology has experienced since Islam's advent and remarked that past and present scholars who have pointed out this crisis in theology and methodology have not been given their due. Along with secularism and technological hegemony, the culture industry has surrounded the world in which the oppressed swelled. He concluded that if Muslims had noticed the transformations in Europe in time and had struggled against this topographic change, they would not have fallen into the same condition as that experienced by the Seven Sleepers, who got into trouble upon waking up and going into the city's bazaar. Güler said that there were still some successful cases, despite all of these adversities, such as the victories that South Africa's Islamist movements gained in the struggle against apartheid. The session was moderated by Edip Asaf Bekaroğlu (Istanbul University; conference co-chair).

This three-day themed conference on Islamism attracted a great deal of attention, and a number of Turkish newspaper columnists wrote their impressions about it. More information on the conference program can be found at $\mathrm{http}: / /$ www.ide.org.tr/detay.asp?ac=haber\&id=110.

Büşra Kırkpınar

M.A. Candidate, Graduate School of Arts and Social Sciences Istanbul Technical University, Istanbul, Turkey 